\title{
Kinetics of the aromatic L-amino acid oxidase from dead bovine spermatozoa and the effect of catalase on fertility of diluted bovine semen stored at $5^{\circ} \mathrm{C}$ and ambient temperatures
}

\author{
P. Shannon and B. Curson \\ New Zealand Dairy Board Artificial Breeding Centre, Newstead, R.D.4, Hamilton, \\ New Zealand
}

\begin{abstract}
Summary. At limiting velocity $50 \times 10^{6}$ dead spermatozoa consumed $13.6 \mu \mathrm{O}_{2} / \mathrm{h}$ and degraded $6.1 \times 10^{-7} \mathrm{~mol} \mathrm{~L}$-phenylalanine/h. Substrate concentration in egg yolk was equivalent to $6.1 \times 10^{-3} \mathrm{M}-\mathrm{L}$-phenylalanine. At a substrate concentration of $3 \times$ $10^{-2}$ M-L-phenylalanine, oxidase activity was significantly affected by oxygen tension $(r=0.947, P<0.01)$ and temperature $(r=0.995, P<0.01)$. Non-return rates were not affected when semen was stored at $5^{\circ} \mathrm{C}$ in $20 \%$ egg yolk diluents with catalase but were significantly increased with semen stored at ambient temperatures of $15-23^{\circ} \mathrm{C}$.
\end{abstract}

\section{Introduction}

Tosic \& Walton (1950) reported that spermatozoa contain an aromatic L-amino acid oxidase (no EC number). One of the end products of $\mathrm{L}$-phenylalanine degradation, $\mathrm{H}_{2} \mathrm{O}_{2}$, is toxic to spermatozoa (Tosic \& Walton, 1950; Mann, 1964: pp. 384-385; Shannon \& Curson, 1972). Tosic \& Walton (1946) also demonstrated that egg yolk, a common constituent of bovine semen diluents, contained dialysable substrates for the enzyme. Although peroxide was produced from egg yolk by bovine spermatozoa, neither reducing the substrate concentration by dialysis of egg yolk (Tosic \& Walton, 1946) nor eliminating peroxide by the inclusion of catalase in semen diluents (Hafs 1961; Foote \& Dunn, 1962) significantly affected fertility when semen was stored in egg-yolk diluents at $5^{\circ} \mathrm{C}$. However, Shannon \& Curson (1972) reported that the enzyme is active only after death of spermatozoa which has enabled a more critical evaluation of the enzyme's properties. The objectives of the present study were to determine (1) activity of the enzyme at various substrate concentrations, oxygen tensions and temperatures; (2) substrate concentrations in egg yolk; and (3) the fertility of diluted bovine semen with and without catalase at $5^{\circ} \mathrm{C}$ and ambient temperatures.

\section{Materials and Methods}

\section{Oxidase activity}

Dead spermatozoa were obtained by freezing freshly ejaculated spermatozoa at approximately $-80^{\circ} \mathrm{C}$. Sperm concentrations were estimated using an absorbtiometer which had been previously calibrated with haemocytometer counts. (Spectronic 20, Bausch \& Lomb Inc; Rochester N.Y. U.S.A.) 
Oxidase activity was measured by the method of Shannon \& Curson (1972). Except when otherwise stated, $50 \times 10^{6}$ dead spermatozoa $/ \mathrm{ml}$ were incubated in $0.1 \mathrm{M}$-sodium citrate, $\mathrm{pH} 7$, with various amounts of L-phenylalanine. Oxygen uptake due to amino acid degradation was measured by adding catalase to the test system when oxygen tension was $70 \%$ of air saturation. The oxygen evolved due to addition of catalase equals half the total oxygen consumed in amino acid degradation. Oxygen consumption was measured by an oxygen probe electrode with the test solution being sealed from air contact (model 55 oxygen monitor, Yellowsprings Inst. Co., Yellowsprings, Ohio, U.S.A.).

Effect of substrate concentration. Oxidase activity was measured at $37^{\circ} \mathrm{C}$ with $50 \times 10^{6}$ dead spermatozoa/ml at L-phenylalanine concentrations of $3 \times 10^{-4}, 1.5 \times 10^{-3}, 7.5 \times 10^{-3}$, $1.5 \times 10^{-2}$ and $3 \times 10^{-2} \mathrm{M}$.

Substrate concentration in egg yolk. Egg-yolk substrates were prepared by dialysing 1 volume of egg yolk against 3 volumes of $\mathrm{H}_{2} \mathrm{O}$ for $48 \mathrm{~h}$ at $5^{\circ} \mathrm{C}$. The diffusate was adjusted to contain $0.1 \mathrm{M}$-sodium citrate and the oxidase activity of dead spermatozoa suspended in the diffusate was determined at $37^{\circ} \mathrm{C}$.

Oxygen tension. Oxygen tension was modified by gassing diluents with nitrogen for various periods and was measured against air-saturated buffer at $37^{\circ} \mathrm{C}$ and recorded as a percentage of $100 \%$ air saturation. The scale on the oxygen meter was then expanded so that the reading was 100 at the start of the test. Substrate concentration was $3 \times 10^{-2} \mathrm{M}$.

Temperature. The oxidase activity in $50 \times 10^{6}$ dead spermatozoa $/ \mathrm{ml}$ was determined at $5^{\circ} \mathrm{C}$ intervals from 15 to $50^{\circ} \mathrm{C}$. Oxygen consumption could not be detected below $15^{\circ} \mathrm{C}$ by the assay method and because of low activity at $15^{\circ} \mathrm{C}$ the sperm concentration was increased to $200 \times$ $10^{6}$ spermatozoa $/ \mathrm{ml}$. Substrate concentration was $3 \times 10^{-2} \mathbf{M}$.

Fertility trials. All semen was diluted in Caprogen (Shannon, 1965) plus 20\% egg yolk. Catalase, when added, was at $4.5 \mu \mathrm{g} / \mathrm{ml}$. Catalase (EC 1.11.1.6) was prepared in crystalline form in this laboratory (see Shannon \& Curson, 1972). Oxygen tension in diluted semen issued to technicians was approximately $40 \%$ of air saturation. Four trials were conducted. In all trials semen was diluted to contain $5 \times 10^{6}$ spermatozoa $/ \mathrm{ml}: 0.5 \mathrm{ml}$ was used per insemination so that the insemination dose was $2.5 \times 10^{6}$ spermatozoa.

In Trial 1 ejaculates from 10 bulls were divided and diluted in Caprogen or Caprogen + catalase. Semen from one bull was used on each day of the experiment. All technicians received both diluents on each day of the experiment. Practical considerations dictated that technicians used semen issued on an experimental day at one storage temperature only. Thus half the technicians used semen issued on one day at $5^{\circ} \mathrm{C}$ and the other half at ambient temperatures. On the next day of the experiment, temperature of use by technicians was reversed. The experiment ran for 10 days, during which time each technician received equal amounts of semen in both diluents, which on 5 occasions they used at $5^{\circ} \mathrm{C}$, and the remaining 5 at ambient temperatures.

The trial was conducted in May and June (autumn) and ambient temperatures varied between 10 and $15^{\circ} \mathrm{C}$. The age of the semen at time of use was 30-54 h. Conception rate was considered to be the percentage of cows not returning to oestrus by 24 days after the first service.

In Trial 2, ejaculates from 15 bulls were divided and diluted in Caprogen or Caprogen + catalase, and the semen was $30 \mathrm{~h}$ old when used.

In Trial 3, catalase was incorporated in all diluted semen on one day of each week during 9 weeks in October, November and December. Semen was routinely collected from each bull $(\mathrm{N}=$ 19) every 3 days so that in each 3 -week period semen was diluted 6 times in diluents without and once in diluent with catalase.

The protocol of Trial 4 was the same as that for Trial 3 except that catalase was incorporated in diluents on 6 days of the week and not on the seventh. A total of 23 bulls was used. In Trials 2, 3 and 4 ambient temperatures were between 15 and $23^{\circ} \mathrm{C}$. Estimates of fertility were 49-day non-return rates to first service. Data were analysed by analysis of variance techniques outlined in Snedecor \& Cochran (1972). 


\section{Results}

\section{Oxidase activity}

Substrate concentration. There was no detectable oxygen uptake when dead spermatozoa were incubated in the buffer without L-phenylalanine. The apparent Michaelis-Menton constant was therefore derived by the method given by Mahler \& Cordes (1966). The correlation between $\mathrm{V}$ and $\mathrm{s} / \mathrm{v}$ where $\mathrm{V}=$ reaction velocity and $\mathrm{s}=$ molar substrate concentration was $-0.976(P<$ $0.01)$. The Michaelis-Menton constant was $3.28 \times 10^{-3} \mathrm{M}$ and at limiting velocity $50 \times 10^{6}$ dead spermatozoa consumed $13.6 \mu \mathrm{O}_{2}$ and degraded $6.1 \times 10^{-7} \mathrm{~mol} \mathrm{~L}$-phenylalanine $/ \mathrm{h}$. Oxidase activity determined by the Briggs-Haldane equation, $\mathrm{Vs} /\left(\mathrm{s}+K_{\mathrm{m}}\right)$, where $V=$ limiting velocity, $\mathrm{s}=$ substrate concentration, and $K_{\mathrm{m}}=$ Michaelis-Menton constant, was significantly correlated $(r=0.996, P<0.01)$ with actual activity (see Table 1$)$.

Table 1. The effect of L-phenylalanine concentration on $\mathrm{O}_{2}$ consumption by dead bovine spermatozoa

\begin{tabular}{cc}
\hline & $\begin{array}{c}\mathrm{O}_{2} \text { consumption } \\
\left(\mu \mathrm{l} / \mathrm{h} / 50 \times 10^{6}\right. \\
\text { Conc. L-phenylalanine }(\mathrm{M}) \\
\text { dead spermatozoa) }\end{array}$ \\
\hline $3 \times 10^{-2}$ & $12.1 \pm 0.2$ \\
$1.5 \times 10^{-2}$ & $11.3 \pm 0.2$ \\
$7.5 \times 10^{-3}$ & $9.3 \pm 0.2$ \\
$3 \times 10^{-3}$ & $7.0 \pm 0.2$ \\
$1.5 \times 10^{-3}$ & $3.8 \pm 0.1$ \\
$3 \times 10^{-4}$ & $1.2 \pm 0.1$ \\
\hline
\end{tabular}

Values are the mean \pm s.e.m. of 12 replicates.

Substrate concentration in egg yolk. Oxygen consumption due to aromatic amino acid degradation by $50 \times 10^{6}$ dead spermatozoa in egg yolk diffusates was $2 \cdot 9,4 \cdot 2,4.9$ and $5 \cdot 1 \mu \mathrm{l}$ $\mathrm{O}_{2} / \mathrm{h}$ in 4 experiments. The estimated L-phenylalanine equivalent was between $8.9 \times 10^{-4}$ and $2.0 \times 10^{-3} \mathrm{M}$ with a mean of $1.5 \times 10^{-3} \mathrm{M}$. The diffusate was equivalent to $25 \%$ egg yolk, and the estimated L-phenylalanine equivalent in whole egg yolk is $6 \cdot 1 \times 10^{-3} \mathrm{M}$.

Oxygen tension. The effect of oxygen tension on oxidase activity is shown in Table 2. The relationship between oxidase activity and oxygen tension is asymptotic $\left(y=-16 \cdot 75+9 \cdot 41 x^{0 \cdot 25}\right)$ $(r=0.947, P<0.01)$ where $y=\mathrm{O}_{2}$ consumption in $\mu \mathrm{l} / \mathrm{h}$ and $x=\%$ air saturation. Predicted activity at 20 and $40 \%$ air saturation is $30 \%$ and $55 \%$ of activity at $100 \%$ air saturation.

Table 2. The effect of $\mathrm{O}_{2}$ tension on $\mathrm{O}_{2}$ consumption $\left(\mu \mathrm{l} / \mathrm{h} / 50 \times 10^{6}\right.$ dead spermatozoa) due to L-phenylalanine degradation

\begin{tabular}{rccccc}
\hline $\mathrm{O}_{2}$ tension & $\mathrm{O}_{2}$ consumption & $\mathrm{O}_{2}$ tension & $\mathrm{O}_{2}$ consumption & $\mathrm{O}_{2}$ tension & $\mathrm{O}_{2}$ consumption \\
\hline $100 \%$ & 12.1 & $60 \%$ & 9.7 & $43 \%$ & 6.7 \\
$100 \%$ & 11.4 & $58 \%$ & $8 \cdot 8$ & $43 \%$ & 6.3 \\
$85 \%$ & 12.1 & $54 \%$ & 10.4 & $41 \%$ & 8.0 \\
$81 \%$ & 12.0 & $52 \%$ & 8.5 & $31 \%$ & 5.6 \\
$79 \%$ & 11.8 & $45 \%$ & 7.8 & $31 \%$ & 4.6 \\
$69 \%$ & 12.0 & $44 \%$ & 7.9 & $23 \%$ & 3.5 \\
\hline
\end{tabular}

Temperature. Enzyme dependence on temperature is shown in Table 3. The effect of temperature on oxidase activity is given by $\log \hat{y}=-4.1007+3.2914 \log t(r=0.995, P<$ 0.01 ) where $t={ }^{\circ} \mathrm{C}$ and $\hat{y}=\mu \mathrm{O}_{2} / \mathrm{h}$. Activity was very dependent on temperature. 
Table 3. The effect of temperature on $\mathrm{O}_{2}$ consumption due to $\mathrm{L}$ phenylalanine degradation

\begin{tabular}{cc}
\hline $\begin{array}{c}\text { Temperature } \\
\left({ }^{\circ} \mathrm{C}\right)\end{array}$ & $\begin{array}{c}\mathrm{O}_{2} \text { consumption } \\
\left(\mu \mathrm{l} / \mathrm{h} 50 \times 10^{6}\right. \\
\text { dead spermatozoa) }\end{array}$ \\
\hline 50 & $31 \cdot 1 \pm 0.4$ \\
45 & $20.5 \pm 0.5$ \\
40 & $13.7 \pm 0.2$ \\
35 & $10.2 \pm 0.3$ \\
30 & $5.3 \pm 0.3$ \\
25 & $4.1 \pm 0.2$ \\
20 & $1.6 \pm 0.1$ \\
15 & $0.3 \pm 0.1$ \\
\hline
\end{tabular}

Values are the mean \pm s.e.m. of 6 replicates.

\section{Fertility trials}

There was an interaction between temperature of storage and catalase addition $(P<0.05)$, with catalase depressing the non-return rates of semen used at $5{ }^{\circ} \mathrm{C}(-3 \cdot 1 \%)$ and increasing them with semen used at ambient temperatures $(+0.4 \%)$ (Table 4$)$. When semen was used at ambient temperatures of $15-23^{\circ} \mathrm{C}$ (Table 5) catalase significantly increased non-return rates with semen used at a mean age of $9 \mathrm{~h}(0.93 \pm 0.25, P<0.01$, combined results of Trials 3 and $4)$ and $30 \mathrm{~h}(1.3 \pm 0.58, P<0.025$, Trial 2 , and $1.73 \pm 0.20, P<0.01$, combined results Trials 3 and 4). Although the results indicate a greater response to catalase inclusion for semen used at a mean age of $30 \mathrm{~h}$ at time of use rather than at a mean age of $9 \mathrm{~h}$, the results cannot be strictly compared because semen of different ages was used by different technicians. However, Trial 2 was conducted with technicians who normally used semen aged $9 \mathrm{~h}$.

Table 4. Percentage non-return rates at 24 days after inseminations with semen stored at $5^{\circ} \mathrm{C}$ or ambient temperatures with or without catalase (Trial 1)

\begin{tabular}{|c|c|c|c|c|c|c|}
\hline \multirow[b]{3}{*}{ Catalase } & \multicolumn{6}{|c|}{ Temperature of storage } \\
\hline & \multicolumn{2}{|c|}{$5^{\circ} \mathrm{C}$} & \multicolumn{2}{|c|}{ Ambient $\left(10-15^{\circ} \mathrm{C}\right)$} & \multicolumn{2}{|c|}{ Mean } \\
\hline & $\begin{array}{l}\text { No. of cows } \\
\text { inseminated }\end{array}$ & $\begin{array}{l}\text { Non-return } \\
\text { rate } \%\end{array}$ & $\begin{array}{l}\text { No. of cows } \\
\text { inseminated }\end{array}$ & $\begin{array}{l}\text { Non-return } \\
\text { rate } \%\end{array}$ & $\begin{array}{l}\text { No. of cows } \\
\text { inseminated }\end{array}$ & $\begin{array}{c}\text { Non-return } \\
\text { rate } \%\end{array}$ \\
\hline 0 & 2088 & 82.5 & 2096 & $83 \cdot 3$ & 4184 & $82 \cdot 9$ \\
\hline $4.5 \mu \mathrm{g} / \mathrm{ml}$ & 2007 & 79.4 & 2047 & 83.7 & 4054 & $81 \cdot 6$ \\
\hline
\end{tabular}

Difference between diluents N.S. Difference between storage temperatures N.S. Interaction of storage temperature and diluent, $P<0.05$.

Table 5. The effect of catalase on percentage non-return rates at 49 days after insemination (no. in parentheses) with diluted semen stored at ambient temperatures $\left(15-23^{\circ} \mathrm{C}\right)$

\begin{tabular}{|c|c|c|c|c|c|c|}
\hline \multirow[b]{2}{*}{ Trial } & \multicolumn{3}{|c|}{ Semen aged $9 \mathrm{~h}$} & \multicolumn{3}{|c|}{ Semen aged $30 \mathrm{~h}$} \\
\hline & No catalase & +Catalasse & $\begin{array}{c}\text { Difference } \\
\pm \text { s.e.d. }\end{array}$ & No catalase & +Catalase & $\begin{array}{c}\text { Difference } \\
\pm \text { s.e.d. }\end{array}$ \\
\hline 2 & - & - & - & $64 \cdot 0(13682)$ & $65 \cdot 3(14169)$ & $+1.3 \pm 0.58$ \\
\hline 3 & $63.9(94671)$ & $64.7(16117)$ & $+0.8 \pm 0.41^{\mathrm{a}}$ & $68 \cdot 1(148286)$ & $69.7(27854)$ & $+1.6 \pm 0.28$ \\
\hline 4 & $63.5(30233)$ & $64.5(146337)$ & $+1 \cdot 0 \pm 0.3^{c}$ & $66 \cdot 2(44126)$ & $68.0(23010)$ & $+1.8 \pm 0.25^{\circ}$ \\
\hline
\end{tabular}




\section{Discussion}

Some general characteristics of the bovine aromatic $\mathrm{L}$-amino acid oxidase have been reported before, namely that the enzyme is active only in dead spermatozoa, is heat, acid and alkali labile and depends on free sulphydryl groups for activity (Shannon \& Curson, 1972). The present kinetic studies show that, at full air saturation of the buffer and at limiting velocity, $50 \times 10^{6}$ dead spermatozoa produce $6 \times 10^{-7} \mathrm{~mol} \mathrm{H}_{2} \mathrm{O}_{2} / \mathrm{h}$. The rate of substrate degradation is similar to that of fructose (see Mann, 1964: p. 294). Unlike respiration of live spermatozoa, which appears not to be affected by oxygen tension until very low levels of oxygen tension are reached (see Mann 1964: pp. 272-273), the activity of the oxidase is affected by oxygen tension. Activity at 40 and $20 \%$ of air saturation was reduced by $45 \%$ and $70 \%$ respectively.

The rate of $\mathrm{H}_{2} \mathrm{O}_{2}$ evolution is governed by the number of dead spermatozoa, substrate concentration, oxygen tension and temperature. In a closed system such as a tube filled and sealed for transport prior to artificial insemination the maximum possible concentration of $\mathrm{H}_{2} \mathrm{O}_{2}$ will also depend on the proportion of dead spermatozoa, because both live and dead spermatozoa compete for available oxygen. At a particular temperature the oxygen tension will be reduced at a constant rate by live spermatozoa (virtually independent of oxygen tension) and by the activity of the aromatic $\mathrm{L}$-amino acid oxidase which is reduced as the oxygen tension decreases but which is increased as the $\mathrm{H}_{2} \mathrm{O}_{2}$ kills more spermatozoa. The time taken to reach the maximum possible concentration of $\mathrm{H}_{2} \mathrm{O}_{2}$ will be markedly affected by temperature of storage, the estimated rate of $\mathrm{H}_{2} \mathrm{O}_{2}$ evolution at $20^{\circ} \mathrm{C}$ being 95 times the rate at $5^{\circ} \mathrm{C}$.

It is probably this effect of temperature which accounts for the difference in response to catalase at different temperatures, i.e. that catalase has no effect or depresses non-return rates at $5^{\circ} \mathrm{C}$ and increases them at ambient temperatures. Because of the small size of the present trials and the low significance reached, such a conclusion can only be tentative, but this postulate is supported by (1) the results of other workers who have shown that catalase does not increase fertility when semen is stored at $5^{\circ} \mathrm{C}$ (Hafs, 1961; Foote \& Dunn, 1962), except possibly after prolonged storage (Foote \& Dunn, 1962); and (2) the consistently positive fertility response we have obtained to catalase inclusion in diluents when semen is stored at ambient temperatures. It follows that catalase is unlikely to be of benefit with deep-frozen semen which is stored at $5^{\circ} \mathrm{C}$ for only a short period before freezing, and is inseminated immediately after thawing (see Foote, 1976). Conversely, catalase inclusion may be valuable when frozen semen is thawed, further diluted and stored at ambient temperature before use (Shannon, 1972), because of the high proportion of dead spermatozoa present after thawing.

\section{References}

Foote, R.H. (1976) Fertility of bull semen frozen with $\beta$-amylase, $\beta$-glucuronidase and catalase. $J$. Dairy Sci. 59, 2014-2017.

Foote, R.H. \& Dunn, H.O. (1962) Motility and fertility of bull semen extended at high rates in yolk extender containing catalase. J. Dairy Sci. 45, 1237-1241.

Hafs, H.D. (1961) Fertility of bull semen with added catalase J. Dairy Sci. 44, 1529-1536.

Mahler, H.R. \& Cordes, E.H. (1966) Biological Chemistry, pp. 228-229. Harper and Row, New York.

Mann, T. (1964) The Biochemistry of Semen and of the Male Reproductive Tract. Methuen, London.

Shannon, P. (1965) Contribution of seminal plasma, sperm numbers and gas phase to dilution effects of bovine spermatozoa. J. Dairy Sci. 48, 1357-1361.
Shannon, P. (1972) The diatube method of freezing semen for use as rediluted deep freeze. Proc. 7 th Int. Congr. Anim. Reprod. \& A.I., Munich 4, 1363-1367.

Shannon, P. \& Curson, B. (1972) Toxic effect and mode of action of dead sperm on diluted bovine semen. $J$. Dairy Sci. 55, 614-620.

Snedecor, G.W. \& Cochran, W.G. (1972) Statistical Methods, pp. 258-298. Iowa State University Press, Ames.

Tosic, J. \& Walton, A. (1946) Effect of egg yolk and its constituents on the respiration and fertilising capacity of spermatozoa. J. agric. Sci., Cambr. 37, 69-76.

Tosic, J. \& Walton, A. (1950) Metabolism of spermatozoa. The formation and elimination of hydrogen peroxide by spermatozoa and effects on motility and survival. Biochem. J. 47, 199-212. 